University of North Florida

UNIVERSITY of

NORTH FLORIDA.

UNF Digital Commons

2009

\title{
Developing Leadership in a Multitype Library Consortium: Ten Years of SEFLIN Sun Seekers
}

\author{
Elizabeth A. Curry \\ University of North Florida, e.curry@unf.edu \\ Jeannette Smithee
}

Follow this and additional works at: https://digitalcommons.unf.edu/library_facpub

Part of the Library and Information Science Commons

\section{Recommended Citation}

Curry, Elizabeth A. and Smithee, Jeannette, "Developing Leadership in a Multitype Library Consortium: Ten Years of SEFLIN Sun Seekers" (2009). Library Faculty Presentations \& Publications. 44.

https://digitalcommons.unf.edu/library_facpub/44

This Article is brought to you for free and open access by

the Thomas G. Carpenter Library at UNF Digital

Commons. It has been accepted for inclusion in Library

Faculty Presentations \& Publications by an authorized

administrator of UNF Digital Commons. For more

information, please contact Digital Projects.

(C) 2009 All Rights Reserved

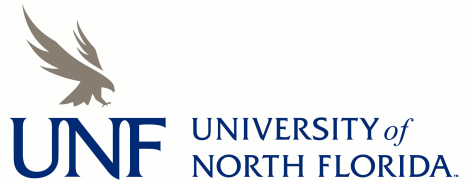


Developing Leadership in a Multitype Library Consortium: Ten Years of SEFLIN Sun Seekers

By Elizabeth A. Curry \& Jeannette Smithee*

* Dr. Elizabeth Curry was executive director of SEFLIN and facilitated the planning of the Sun Seekers Institute in 1996 with the SEFLIN Library Administration and Management Committee (LAM). Dr. Curry facilitated the first institute and when she left SEFLIN she was later hired as a consultant to continue facilitation. Jeannette Smithee is the current Director of Staff Development Services and coordinator of the Institute.

June 28, 2009/July 26,2009

Elizabeth A. Curry PhD

President, Curry's Consulting Services Inc.

Jeannette Smithee, Director of Staff Development Services, SEFLIN, Inc.

\footnotetext{
ABSTRACT

The Southeast Florida Library and Information Network (SEFLIN) has presented the Sun Seeker Leadership Institute biennially since 1997. SEFLIN, a multitype library consortium headquartered in Boca Raton, Florida, was one of the first groups to sponsor a library leadership institute held as a monthly series of events over the period of a year. One hundred library staff members from all types of libraries, large, small, public, and academic, have completed the leadership institute. After twelve years and six cohorts, SEFLIN is reviewing the project's impact. This article outlines how and why the leadership institute was created, the program's goals and format, and presents the results of a survey of past participants. The authors suggest further study of how participants are affected by the leadership styles modeled by their supervisors.
} 


\section{BACKGROUND}

For over ten years, the Sun Seeker Leadership Institute has assisted southeast Florida's libraries to develop high quality leadership skills among their staff members. A majority of Sun Seeker alumni report that their involvement in the Institute directly led to greater engagement in professional activities, positions of more responsibility, and a self-concept as a library leader. Today, Sun Seeker alumni give back to the Leadership Institute by serving as mentors and "Personal Reflections on Leadership" speakers. The Institute reflects SEFLIN's highly successful collaborative philosophy. While Sun Seeker participants benefit from training, local institutions and the profession at large benefit from the leadership skills and expertise developed by participants. Through the Leadership Institute, SEFLIN has reinforced both the professional and the social network of the alumni and mentors, which will support and stimulate future collaboration in the region. As one participant commented:

One of the best things about the Sun Seekers program is networking with professionals from outside your own system. As single systems, the participants could not have organized [the multitype format] presentations. Only SEFLIN could have managed this and it is exactly the kind of thing that consortia should be involved in.

SEFLIN continually seeks to improve the instructional model for the Sun Seeker Leadership Institute by building on the most successful elements of each Institute, as determined by participants. Dr. Curry provides instruction for the program, using The Leadership Challenge 
(Kouzes \& Posner, 2002) as the core curriculum. Other important factors in the longevity and success of the Sun Seeker Leadership Institute include:

- Involvement of SEFLIN's Library Administration and Management Committee in recruiting, supporting and evaluating Sun Seekers;

- Sun Seeker participation in a Team Ropes Adventure Challenge (TRAC) course event at Florida International University;

- Engagement of experienced professionals who serve as mentors; and

- Presentations by outstanding library leaders who share their Personal Reflections on Leadership.

Uncertain Future Succession and Leadership Succession planning and leadership development are critical issues for libraries everywhere, not only in Florida (Bridgland, 1999; Curran, 2003; Summerfield, 2002; Whitmell, 2002). As the Baby Boomer generation begins to retire in significant numbers, it is becoming clear that the inadequate preparation of emerging leaders will significantly hamper libraries' ability to meet the future information needs of the communities they serve. An Association of Research Libraries survey of Canada and the United States determined that librarians as a group are generally older than national Boomer statistics, so libraries are on the leading edge of addressing this issue. The loss of so much intellectual and social capital could potentially have a negative impact on organizations and services. While this loss will not happen overnight, and retirement is difficult to calculate except based on age, predictions have suggested a loss of 25 to 47 percent of the current librarian[FGCU1] workforce in America in the next six to 10 years (American Library 
Association (ALA) Washington Office, 2004; Hernon, Powell, \& Young, 2003; Lynch, 2002; Meredith, Schewe, Hiam, \& Karlovich, 2002; Whitmell, 2002). Economic constraints, the trend toward downsizing in government, flattened organizational structures, lack of adequate time for systematic training, limited career ladders, competition for those with library skills and low salaries are among the factors that have contributed to a shortage of qualified professionals with the necessary leadership skills. In many cases, libraries have not been able to provide adequate opportunities for the next generation of leaders to prepare for the future.

The current worldwide economic crisis could have an unintended benefit for the development of future library leaders. Delayed retirements and layoffs will slow the rate of leader turnover, which could create an opportunity to conduct more leadership training. On the other hand, the very same situation may drive emerging leaders from the profession due to lack of career opportunities. Either way, there is more to the future than coping with changing demographics and recruiting entry-level staff. Equity of all types has been an ongoing issue in the library and information management field. Diversity in ethnicity and gender are areas of concern that must continue to be actively addressed. The profession struggles to recruit more minorities into the field in order to adequate: ely represent and serve diverse communities, and minorities must also be represented at the highest levels of leadership.

Another type of diversity—generational diversity — and the resulting implications for managing organizations is a new concern in business that will be critical for the library profession as well (Lancaster \& Stillman, 2002; Zemke, Raines, \& Filipczak, 2000). Some researchers detail seven American Cohorts, defined as groups of people who came of age at roughly the same time: 
Depression, World War II, Postwar, Leading Edge Boomers, Trailing Edge Boomers, Generation $\mathrm{X}$ and Generation N (Meredith et al., 2002)[FGCU2]. Each of these groups has developed different outlooks, values and work ethics. The career expectations of Generation X and their goals for their work are quite different from those of the Traditionalists, Postwar or Baby Boomers. Already we have seen some competent librarians who are not interested in becoming directors because they want a more balanced, flexible lifestyle, which they perceive as incompatible with a demanding leadership role. Yet, at the same time, Generation X people are known for being entrepreneurial workers who value lifelong learning. They are characterized by independence rather than collaboration and are impressed by competence, not just positional authority[FGCU3] (Raines, 1997).

More [FGCU4] than ever before, the leaders of tomorrow will need the skills to communicate and develop relationships with diverse populations. The practical outlook of those born before 1946 became characterized as more optimisticsfor the Boomers and skeptical for the Gen Xers. Predictions for the Gen $\mathrm{N}$ or Nexters is one of optimisim. Traditional respect for hierarchy gave way to the Boomers' desire for consensus and the Gen Xers respect for individual achievement. The team orientation of many Boomers may need to be balanced with the self reliance and independence of the Gen Xers (Raines, 1997, Zemke,Raines \& Filipczak, 2000). The future will require leaders to adapt to diverse generational cultures and solve problems creatively rather than to rely on past routines. Leaders will focus more on the environment, trends, opportunities for collaboration and community needs rather than looking primarily at current institutional practices and policies (Bennis, Spreitzer, \& Cummings, 2001; Kouzes \& Posner, 2002). To meet these needs, a comprehensive, long-term approach to leadership development is critical. 


\section{Defining Leadership}

In order to successfully outline and implement a leadership development plan, a common understanding of the defining elements of leadership is necessary. Scholars from numerous disciplines have studied leadership for hundreds of years, with the main conclusion that it is a very complex and sometimes ambiguous concept. James McGregor Burns, a Pulitzer Prizewinning figure in the field of leadership study, concluded that leadership is "one of the most observed and least understood phenomena on earth" (Witherspoon, 1997, p. ix). One author identified more than 100 definitions of leadership, such as situational leadership, servant leadership, emotional intelligence, and team leadership (Riggs, 2001). Much of the literature agrees on the fundamental point that satisfactory leadership enhances the likelihood that an organization will meet its goals, but definitions differ widely. Generally, definitions of leadership can be classified in terms of their emphasis, which are on (1) traits, (2) skills, (3) styles, (4) contingency and (5) team or group or a combination thereof. The Next Library Leadership: Attributes of Academic and Public Library Directors offers a comprehensive inventory of personal and professional qualities that are both management and leadership traits in the group they studied (Hernon et al., 2003). The Center for Creative Leadership reports that a leader's relationships with subordinates and others is the most significant factor leading to successful leadership[FGcu5] (Kouzes \& Posner, 2002),. Warren Bennis, Kouzes \& Posner, Daniel Goleman and others propose that "managing self" - the ability of leaders to understand themselves and others - is critically important (Goleman, Boyatzis, \& McKee, 2002). Patricia Witherspoon elaborates on the concept of leadership as self awareness and adds that leadership is a relationship-building process based on communication (Witherspoon, 1997). Leaders must be 
Developing Leadership in a Multitype Consortium

able to communicate effectively in order to achieve goals in areas such as change, community building, visioning, political skills, strategic planning and teamwork.

Any leadership development program needs to introduce participants to the variety of theories defining leadership and encourage library leaders to develop their own understanding of their personal leadership qualities. The challenge is to balance the conceptual and philosophical foundations with the practical skills, while providing opportunities for dialogue, self-reflection and assessment. The complexity of leadership means that the learning process is equally complex and to a large extent individualized. A holistic approach to personal development of leadership is a process, not a quick fix (Doh, 2003). Adult learners require a variety of techniques and learning styles[FGCU6] must be incorporated into any leadership program (Doh, 2003). Training includes modeling, coaching, feedback, experiential activities, personal assessments, and a safe place to experiment, explore and take risks. To benefit from leadership development projects, participants must have motivation, the capacity for strategic thinking, basic communication skills, emotional intelligence, orientation toward learning and the desire to lead (Doh, 2003). Schreiber and Shannon discuss the advantages of identifying individuals with certain leadership traits and infusing their careers with specifically designed training experiences in order to advance a cadre of library leaders. Information environments require the best use of personnel, who must be trained to identify and respond to changing demands and the marketplace. Leadership development is a "life-long endeavor" achieved by encouraging the newly initiated and by further developing library professionals (Schreiber \& Shannon, 2001).

SEFLIN Sun Seekers Leadership Institute 
The Southeast Florida Library Information Network (SEFLIN) was founded in 1984 as a nonprofit membership organization of Southeast Florida libraries dedicated to supporting cooperation between all types of libraries. SEFLIN's thirty-two (32) member libraries/library systems in four counties in Southeast Florida, Miami-Dade, Broward, Palm Beach, and Martin, have over 2,000 staff (FTE) in 335 service outlets serving almost 3 million registered borrowers or full time students. Since its inception, one of SEFLIN's core values has been collaboration. Member libraries are expected to be, actively involved in sharing information, identifying common needs and developing projects. SEFLIN's vision is to be a leading library cooperative, supporting library organizations in transcending boundaries and working collaboratively to improve library services. The mission of SEFLIN includes fostering cooperation among member libraries and partners for the purpose of advancing staff development, information services, and resource sharing. In the context of SEFLIN's committee structure the Sun Seekers Leadership Institute was proposed in 1996.

History

In 1996 the SEFLIN Library Administration \& Management (LAM) Committee saw the need for leadership development in their institutions and by working together, they developed a project that is continuing to shape their collective future. At the time, the LAM Committee was comprised of representatives from eight academic libraries, including public and private, two-year and four-year institutions, as well as five city- and county-based public library systems. The LAM Committee members, all assistant or associate directors of member libraries, had a vested interest in the success of the Institute and they also had the power and influence to recruit participants and to provide resources for the Institute. During early planning sessions, LAM members discussed the need to address both practical management 
skills, as well as higher-level, conceptual leadership skills. These discussions benefited the committee members as they clarified their needs and explored what they meant by "leadership." (This discussion continues, ten years on, between the LAM Committee and the Leadership Institute participants.) The LAM Committee surveyed member library directors to determine what they expected of future leaders and which topics they thought should be addressed.

In 1996 a popular model of leadership training was immersion in the topic during a weeklong institute in a retreat environment[FGCU7]. (I don't want to use an example because it looks like I'm directly comparing effectiveness of others.) The time and resources required for this approach concerned the committee, so they explored other models. When LAM first discussed holding monthly sessions over 9 to 12 months instead of an institute lasting a full week, many were concerned about a potential weakening of the institute's effectiveness and impact. Some people worried that "it just wouldn't work." The LAM committee and SEFLIN staff probed even deeper and asked the question, "What would it take to make it work?"

The long-term goals established for the Sun Seeker Leadership Institute are:

- To develop library staff who have the potential to lead 21 st century libraries;

- To develop a cadre of mentors who will act as guides, coaches and role models;

- To provide a high-quality leadership program for emerging library leaders which will instill progressive and effective leadership strategies, attitudes and skills; 
- To encourage participants to recognize and/or initiate innovations, seize opportunities and take risks where appropriate;

- To guide participants to appreciate and thrive in a changing political and demographic environment; and

- To serve as a mechanism for continuing leadership development among Sun Seekers alumni and a broad based library leadership network.

The LAM Committee and SEFLIN staff did not include a goal which addressed multitype library cooperation specifically. Perhaps they took for granted that a network of relationships among various types of libraries would naturally arise as a result of the Institute, and indeed, as the librarians who founded SEFLIN and other cooperatives have been retiring, a new group of leaders with a strong collaborative philosophy has arisen. In 2007-2008 the LAM Committee had expanded to 24 members, six of whom (or 25 percent) were Sun Seekers Leadership Institute alumni. The chair of the LAM Committee was a Sun Seeker alumnus. SEFLIN continues to see alumni participation in other SEFLIN leadership positions and committees, as well as in state and national associations.

Format \& Content of the Institute

After the LAM Committee established the institute's goals and format, they discussed options for facilitation and coordination. After reviewing proposals the committee asked the SEFLIN executive director, Elizabeth Curry to develop the institute and facilitate the sessions. The continuity of one facilitator throughout the year has proven to be a success factor because the participants build a relationship with the facilitator and gain the sense of trust necessary for risk taking. In order to introduce the participants to a variety of leaders, to expose participants to 
Developing Leadership in a Multitype Consortium

different leadership styles and to offer participants one-on-one coaching, the committee formulated two complementary and critical aspects of the Institute: Personal Reflections on Leadership and the Mentoring Program.

\section{Personal Reflections on Leadership}

Sun Seeker Institute participants learn that they need to find their own authentic leadership style based on their values and communication styles. Reading about developing personal style and credibility is important, but seeing it demonstrated is much more powerful. The Personal Reflections segment is a time during each session when a leader from the region shares his or her "Top 3" skills, knowledge, and abilities that have proven important in their career. We encourage speakers to share stories from their careers and to elaborate on the process of becoming a leader. Several dramatic examples stand out from the past. During one session, the first presenter stressed that leadership meant making tough decisions, being able to deal with conflict and strongly adhering to your principles. The second speaker talked about how important listening, patience and trust were in leading others and building a highly motivated team. After the speakers left, the Sun Seekers had a lively discussion about these different ways of leading and what they meant for developing their own personally authentic styles. They also discussed how different styles work in different organizations during different times. One speaker was a statewide leader who admitted to being a basically shy person who had become an “accidental" leader. Several Institute participants shared that his presentation inspired them because they worried about their own personalities being too low-key to be effective. Another Sun Seeker participant shared that this session had led him to a better appreciation of quiet leaders. 
The Personal Reflections segment of the institute has proven significant in other ways. Institute participants have the opportunity to network with established leaders, seek advice, and receive informal mentoring. They develop valuable social capital. The speakers become more involved in the Institute and many comment on the benefit to them in reflecting on their own leadership skills. Several Sun Seeker participants remarked that they had never heard their own director discuss leadership until the Personal Reflections presentation. Sun Seekers' reactions to speakers vary depending on their needs; some want to hear from newer leaders, some want to hear from established leaders, and SEFLIN strives for diversity, considering a variety of factors including experience, type of library, ethnicity, gender, expertise, and presentation styles. In recent years the Institute has included alumni as Personal Reflections speakers.

\section{Mentoring}

The Mentoring Program component of the Institute continues to evolve. Jeannette Smithee, Director of Staff Development Services for SEFLIN, coordinates the Mentoring Program by contacting the Sun Seekers and Mentors throughout the year. Mentors include LAM Committee members, library directors, assistant directors, department heads and librarians, who volunteer and post their profiles on-line for Sun Seekers to review. Mentors are expected to attend the kick-off mentoring workshop, the mid-year reception and the final celebration. Some of these mentoring relationships last for one year and some last longer; some are in-depth interactions and others are more casual. We found that in order for the mentoring program to succeed, guidelines and expectations for mentors and Sun Seekers are critically important. These are provided in 
workshops and in writing. More recent cohorts have included Sun Seeker alumni as mentors, which deepens their understanding of the process, expectations and challenges of mentoring.

Time, distance and expectations can all present challenges to a successful mentorship experience. Survey comments from Sun Seekers illustrate some of these difficulties, as well as some of the benefits of the mentorship program:

The mentoring aspect of the program was the least successful for me. Both my mentor and I were extremely busy that year, and we never really made the time to work together.

I didn't get to meet with my mentor as much as I would have liked. Nevertheless, at one of the sessions - and this was at a social period, not one of the formal meeting times - she said something in passing that caught my attention. The more I thought about it, the more I took it to heart, and it really made me change my thinking about where I wanted my career to go and how best to get there.

Having a mentor and talking to her about my career and having her guide my decisions -- not making them for me, but making me think about the decisions I could make on my own -- was so liberating. With such support I made a goal and followed it through. The Sun Seekers program and my mentor have put me onto a broader path. I've become better at decision-making and more confident... As a result I'm a more competent and reliable supervisor. 


\section{Additional Program Content}

The remaining content of the SEFLIN Sun Seekers Leadership Institute sessions is based on the five practices from The Leadership Challenge by James M. Kouzes and Barry Z. Posner (2002): "Model the Way," "Inspire a Shared Vision," "Challenge the Process," "Enable Others to Act" and "Encourage the Heart" (Figure 1). The authors present examples of research, personal stories, and practical exercises within the framework of these practices. Based on the practices and commitments, the SEFLIN Sun Seekers Leadership Institute covers such topics as: defining management and leadership, organizational cultures, organizational values, vision, innovation, risk taking, trust and credibility, styles of influence, change management, framing, persuasion, message development, communication techniques, listening styles, collaboration, team building, meeting and project facilitation, empowerment, motivation and recognition. The content is adapted to the needs and interests of each cohort. Each participant receives a copy of the book and is expected to read assigned chapters prior to the sessions. Additional inventories[FGCU8] of personal practices, checklists of behaviors and articles are distributed in advance as a "Sneak Peek \& Homework" packet. This helps the participants prepare for a thoughtful discussion, and benefits those who need more time to think before sharing their ideas.

One of the most critical aspects of the Institute is the modeling of the skills we discuss during the sessions, creating a safe space for taking risks and experimenting while encouraging a collaborative learning style where all voices are valued. Addressing a diverse range of learning styles requires that many different approaches be modeled. Small group activities are used extensively for discussion, as well as interactive, experiential exercises: from readers' theater and acting out stories, tossing balls, building with blocks, and drawing, to problem solving scenarios, 
role playing and group discussions. We have fun with the exercises, as well as with memory anchors and door prizes, because research strongly suggests that "when people feel good their thinking becomes more creative, integrative, flexible and open to information" (Fredrickson, 2003). Positive emotions lead to the discovery of novel ideas, pursuit of innovative actions and development of stronger social bonds. (Note: A "memory anchor" is an item used as a concrete representation of the theme for the day. For example, a stone elephant figurine was used to reinforce a fable and the idea: Leadership is like an Elephant. If you focus on one part, it is hard to see the big picture.)

A Team Ropes Adventure Challenge (TRAC) day is included in the curriculum in support of team building and personal risk taking. At the end of a session, one participant observed. "When I proposed an idea in a committee at work, people wanted to tell me why it wouldn't work. At the ROPES class, even when I fell off the high beam and was dangling from a harness, people pulled the ropes tight and kept telling me I could do it!" To "Encourage the Heart" and celebrate the ROPES day we take photographs, which often become part of the final celebration, which is planned each year by the Sun Seekers themselves. In 2008 SEFLIN celebrated the tenth anniversary of the Sun Seekers Leadership Institute with a special program reflecting on the Institute's inception, progress, participant experiences and outcomes

Alumni Surveys 2003 and 2009

In order to get a longer-term view of the participation outcomes, we surveyed alumni in 2003 and 2009. In 2003 an email survey was sent to the 70 Sun Seeker alumni who had completed the program between 1998 and 2002. The 2009 survey was online; notices were sent to the 122 Sun 
Seeker alumni who had completed the program through 2008. Thirty-nine responses were received in 2003 and 60 responses were received in 2009 (see figure 2.). The 2009 survey included 21 Sun Seekers from the classes of 1998-2002 (35\%) and 49 Sun Seekers from the classes of 2004-2008 (65\%).

In the 2003 survey, $72 \%$ of the Sun Seekers reported that they had assumed additional responsibilities in the library. Forty-four had received a job promotion. In the 2009 survey, $76 \%$ reported assuming additional responsibilities, receiving a promotion or accepting a new position. In both surveys, the Sun Seeker experience was reported by alumni to be a very positive or positive influence on those who reported career changes (87\% in 2003 and 85\% in 2009). Survey comments included:

Sun Seekers must have contributed to my professional growth because ... I have been elected ALA Councilor-at-Large, changed jobs and gotten big raises, and assumed more committee work in professional associations. This broadening of my professional horizons has brought me professional recognition and much personal satisfaction. I have never been busier or happier in my career. I am enjoying it more than ever. Sun Seekers made me recognize professional contribution opportunities and I have consequently been more confident to seize opportunities. ...Ultimately, it is about making a contribution to our profession. Where can I serve to make a greater contribution? This value of contributing back to the profession is shared, I believe, in the work and contributions of our Sun Seeker Mentors not only within the SEFLIN community, but nationally, as well. 
After participating in the program, I felt greater confidence in my leadership abilities, and went on to chair committees in SEFLIN and ALA, as well as in my own library. I also became more involved in professional activities, including giving some presentations and writing a journal article. As a result of these (and other) activities, I successfully underwent the promotion process in my library. I do feel that the Sun Seekers program played a significant role in this happening.

My library system stresses outreach into the community by all Branch Managers. The leadership workshops empowered me to accept the position of Secretary of my Rotary club which leads me to the VP position next year and Presidency in 2005. I've also accepted the position of Treasurer for the local garden club. These positions reinforce professional traits that I will need when I choose to become a library administrator.

In the 2003 survey, $64 \%$ of the Sun Seekers reported increased professional service (such as activities in professional organizations or library committees, writing articles, etc.). In 2009, 58\% reported an increase in professional service. In 2003, $73 \%$ of the respondents who had increased their professional service reported that the Sun Seeker experience had a very positive or positive impact on their increase in professional service. In 2009, $84 \%$ of the Sun Seeker respondents who increased professional service said that the experience had a very positive or positive impact on them. In the 2003 survey, respondents were asked to rank the Sun Seeker Leadership Institute compared to other professional development activities they had experienced. It was ranked best 
by $34 \%$, better by $55 \%$, and the same by $11 \%$. Comments such as these from the 2003 survey supported the value of the Institute for the participants:

Being a Sun Seeker allowed me to learn how to think beyond the job I was doing and see the library as a whole as well as its pieces. I am probably a much better librarian because of this year.

I would recommend the Sun Seeker program to anyone who needs a boost in their career, whether it's in the library setting or not. The benefits are fantastic and you get so much out of it professionally and personally that it can only be called a great experience. I think it should be a mandatory program for anyone that wants to move ahead in their career or learn to be a leader.

The 2009 survey did not ask the Sun Seeker alumni to compare the experience to other professional development activities. Instead, respondents were asked if the practices of leadership they learned in the Sun Seeker Institute affected their confidence, their ability to guide their career, and their ability to lead others. Of the 60 responses, $43 \%$ reported a very positive impact, $45 \%$ reported a positive impact and only $7 \%$ reported no impact. Comments from participants supported the value that the participants place on the Sun Seeker experience: The Sun Seeker program provides a unique opportunity to be exposed to all facets of library leadership. I found the mentoring extremely beneficial, and the handson teamwork has had a lasting positive influence! 
Developing Leadership in a Multitype Consortium

Sun Seekers was one of the best experiences of my life. It challenged me to think outside the box and to push myself beyond my comfort zone. I highly recommend this institute and the ideas it fosters which we all put into practice.

Sun Seeker class participants have been selected from academic and public libraries throughout the SEFLIN region. This aspect of the leadership institute has added an understanding of the issues and problems related to leadership across libraries. In 2009, the survey asked the Sun Seekers if the interactions with people from libraries other than your own made an impact on their understanding of library leadership. Of the 60 responses, $42 \%$ reported a very positive impact, 52\% reported a positive impact, and 6\% reported no impact. Several people noted the value of participating with Sun Seekers from other types of libraries.

That has also been a way of touching base with participants from other libraries, as I frequently see familiar faces from Sun Seekers at FLA and SEFLIN events. I also gained a greater understanding and appreciation for librarians working in environments other than my own.

Though the 2003 survey did not ask a direct question about the value of the leadership training with participants from many types of libraries, several of the respondents commented on the value of learning from those in other libraries.

SEFLIN sees leadership training as a long term investment for the member libraries. As a SEFLIN Board member recently commented, "It may be three to five years after the Institute before the library can fully benefit from the rewards the Sun Seeker's leadership 
Developing Leadership in a Multitype Consortium

experience." These long term outcome surveys help SEFLIN to gauge the value of the Leadership training through the Sun Seeker Leadership Institute. The self-selected respondents represent about half of the Sun Seeker alumni (56\% in 2003 and $49 \%$ in 2009), but the responses and experiences they report reflect the full range of Sun Seeker alumni. Though less than half of the alumni reported promotions and only a handful of Sun Seekers have entered upper management in libraries, a much larger number have reported changes and increased responsibilities in their current positions or levels in the library organizations. The 2009 survey comments also revealed that the Leadership Institute many Sun Seekers to complete their MLS degrees. One Sun Seeker passionately described the impact:

I took on greater responsibilities, including a threefold increase in staff supervision. Simultaneously, my personal and professional life has improved immensely. In fact, I am better positioned and more willing to tackle critical decisions now than I was prior to attending and completing the program. The Sun Seeker Institute is definitely changing lives, personally and professionally for the better...you impact and instill something college and university did not do for me, the WILL TO ACT...even when it hurts.

The Sun Seeker Leadership Institute has been widely recognized. In 2004-2005 it was the model used by the State Library of Florida to develop their Sunshine State Library Leadership Institute. 
The state model has evolved, but it continues to place a strong emphasis on leadership development. The State Library has also sent middle- and senior-level managers to symposia offered by SOLINET throughout the state, in response to the need for practical as well as conceptual training.

Each year the LAM Committee and staff review format and content while Sun Seekers evaluate each session. Both groups participate in a final focus group during the last session. The facilitator meets with SEFLIN staff and LAM representatives to explore ideas for the future. There is continuing discussion about how much experience a participant should have before attending, the desirability of having cohorts with staff in similar positions (such as reference or youth services) and how to balance conceptual frameworks with practical skills. From the surveys and informal feedback that SEFLIN has gathered, the results of the current model have been very positive.

Since 1997 SEFLIN's leadership training has been funded by both state and local funds. SEFLIN received LSTA (Library Services and Technology Act) funding administered by the State Library of Florida and member libraries paid a fee to cover expenses not covered by the grant. In the current economic climate, with lean staffs and low funding, finding time and money to send participants can be challenging for consortia and member libraries. This, however, is the time when we need to ensure that we will have leaders for the future.

In closing, we want to present a somewhat provocative issue for consideration. Dr. Curry has found that after facilitating leadership institutes for SEFLIN, public libraries, state projects and 
other clients there is a critical concern which arises in almost every cohort. After about three to four sessions, a participant comments on the value of the Institute but observes that his or her current supervisor, branch manager, department manager, or director does not practice the leadership skills we have read and discussed. Other participants usually agree, and add that they wish their supervisor, department head, director and/or their coworkers could attend the Institute. Modeling is a very powerful teaching and learning method, so this disjunction presents an interesting issue for class discussion. Curry encourages participants to model their values, share information and set their own goals as they become the leaders of the future.

At the same time, we hear many leaders remark that leadership institutes did not exist as they progressed through their careers. If these library leaders are delaying retirement (for economic or other reasons), this would be an ideal time to conduct an institute targeted to this group, as a way to become re-inspired and more aware of generational diversity, changing needs and styles of leadership. Another form of training might be executive coaching for established library managers and leaders.

Living these leadership concepts is both a challenge and an ongoing process. Building any skill takes time: time to think about leadership, to explore ideas, and to embrace new ways of working. We conclude with a simple but profound definition of leadership from Kouzes and Posner: "Leaders are learners, and learners are leaders" (Kouzes \& Posner 2002).

Complete information about the Sun Seeker Leadership Institute is available online at http://www.seflin.org/clp/index.cfm?fuseaction=pages.SunSeekerHistory. This page links to 
Developing Leadership in a Multitype Consortium

directories of previous Sun Seekers, calendars of events, evaluation survey results, lists from the mentoring process, and photos from previous years. 


\section{References}

ALA Washington Office. (2004). Action Alert. ALAWON (American Library Association Washington Office Newsline), 13(31).

Bennis, W., Spreitzer, G. M., \& Cummings, T. G. (Eds.). (2001). The future of leadership: Today's top leadership thinkers speak to tomorrow's leaders. San Francisco: Jossey-Bass.

Bridgland, A. (1999). To fill or how to fill--That is the question succession planning and leadership development in academic libraries. Australian Academic \& Research Libraries, 30(1), 20-29.

Curran, W. M. (2003). Succession: The next ones at bat. College and Research Libraries, 64(2), 134-140.

Doh, J. P. (2003). Can leadership be taught. Academy of management, learning \& education, 2(1), 54-67.

Fredrickson, B. (2003). The Value of Positive Emotions. American Scientist. 91(July-August), 330-335. (www.americanscientist.org)

Goleman, D., Boyatzis, R., \& McKee, A. (2002). Primal leadership: Realizing the power of emotional leadership. Boston: Harvard Business School Press.

Hernon, P., Powell, R. R., \& Young, A. (2003). The next library leadership: Attributes of academic and public library directors. Westport, CT: Libraries Unlimited.

Kouzes, J. M., \& Posner, B. Z. (2002). The leadership challenge (Third ed.). San Francisco: Jossey-Bass.

Lancaster, L. C., \& Stillman, D. (2002). When generations collide: Who they are. Why they clash. How to solve the generational puzzle at work. New York, NY: HarperCollins Publishers. 
Lynch, M. J. (2002). Reaching 65: Lots of librarians will be there soon. American Libraries, 33(3), 55-56.

Meredith, G., Schewe, C. D., Hiam, A., \& Karlovich, J. (2002). Managing by defining moments. New York, NY: Hungry Minds.

Raines, C. Beyond generation X:Apractical guide for managers.Menlo Park, CA:Crisp Publications.

Riggs, D. E. (2001). The crisis and opportunities in library leadership. Journal of Library Administration, 32(3\&4), 5-17.

Schreiber, B., \& Shannon, J. (2001). Developing library leaders for the 21 st century. In M. D. Winston (Ed.), Leadership in the library and information science professions: Theory and Practice (pp. 35-57): Haworth Press.

Summerfield, M. (2002). CLA's human resources and succession planning survey: Analysis and recommendations. Canadian Library Association, 48(4), 188-189.

Whitmell, V. (2002). Library succession planning: The need and challenge. Australian Public Libraries and Information Services, 15(4), 148-154.

Witherspoon, P. D. (1997). Communicating leadership: An organizational perspective. Boston: Allyn and Bacon.

Zemke, R., Raines, C., \& Filipczak, B. (2000). Generations at work: Managing the clash of veterans, boomers, Xers and nexters in your workplace. New York, NY: AMACOM (American Management Association). 
Figure 1.

THE LEADERSHIP CHALLENGE by James M. Kouzes and Barry Z. Posner

FIVE PRACTICES \& TEN COMMITMENTS

\section{MODEL THE WAY}

1. Find your voice by clarifying your personal values.

2. Set the example by aligning your actions with shared values.

\section{INSPIRE A SHARED VISION}

3. Envision the future by imagining exciting and ennobling possibilities.

4. Enlist others in a common vision by appealing to shared aspirations.

\section{CHALLENGE THE PROCESS}

5. Search for opportunities by seeking innovative ways to change, grow and improve.

6. Experiment and take risks by constantly generating small wins and learning from mistakes.

ENABLE OTHERS TO ACT

7. Foster collaboration by promoting cooperative goals $\&$ building trust.

8. Strengthen others by sharing power and discretion.

\section{ENCOURAGE THE HEART}

9. Recognize contributions by showing appreciation for individual excellence.

10. Celebrate values \& victories by creating a spirit of community. 
Developing Leadership in a Multitype Consortium

Figure 2

\section{Sun Seeker Long Term Outcomes 2009}

Total Surveys Submitted: 60

1. How much do you think the five practices of leadership, learned in the Sun Seeker Institute, impacted your confidence, ability to guide your career and ability to lead others in the library profession?

$\begin{array}{lrr}\text { Very positive impact } & 26 & 43.33 \% \\ \text { Positive impact } & 27 & 45.00 \% \\ \text { No impact } & 7 & 11.67 \% \\ \text { Negative impact } & 0 & 0.00 \%\end{array}$

2. Have you assumed additional job responsibilities, a promotion, or a new position in a library since you participated in the Sun Seekers Leadership Institute?

$\begin{array}{lll}\text { Yes } & 46 & 76.67 \% \\ \text { No } & 14 & 23.33 \%\end{array}$

3. If yes, what impact did your experience as a Sun Seeker have on your career change(s)?

$\begin{array}{lrc}\text { Very positive impact } & 17 & 35.42 \% \\ \text { Positive impact } & 24 & 50.00 \% \\ \text { No impact } & 7 & 14.58 \% \\ \text { Negative impact } & 0 & 0.00 \% \\ \text { No Answer Given } & 12 & \end{array}$

4. Did the interactions with people from libraries other than your own during the Sun Seeker Institute have an impact on your understanding of the roles of leadership in libraries?

$\begin{array}{lrr}\text { Very positive impact } & 25 & 41.67 \% \\ \text { Positive impact } & 31 & 51.67 \% \\ \text { No impact } & 4 & 6.67 \% \\ \text { Negative impact } & 0 & 0.00 \%\end{array}$

5. Have you become more active in professional associations and library committees, or written articles, etc. since the time you attended the Sun Seekers Leadership Institute?

$\begin{array}{lll}\text { Yes } & 35 & 58.33 \% \\ \text { No } & 25 & 41.67 \%\end{array}$

6. If yes, what impact did your experience as a Sun Seeker have on your external professional activities?

Very positive impact

Positive impact

No impact

Negative impact

No Answer Given

7. In what year were you a Sun Seeker?

$\begin{array}{lrc}1997-1998 & 4 & 6.67 \% \\ 1999-2000 & 10 & 16.67 \% \\ 2001-2002 & 7 & 11.67 \% \\ 2003-2004 & 10 & 16.67 \% \\ 2005-2006 & 17 & 28.33 \% \\ 2007-2008 & 12 & 20.00 \%\end{array}$

